\title{
Anti-Inflammatory Effect of Gold Nanoparticles Supported on Metal Oxides
}

\section{Takeshi Fujita ( $\nabla$ fujitatks@stf.teu.ac.jp )}

Research Center for Gold Chemistry, Department of Applied Chemistry for Environment, Graduate School of Urban Environmental Sciences, Tokyo Metropolitan University, 1-1Minami-osawa, Hachioji, Tokyo 19

\section{Maéva ZYSMAN}

Univ Bordeaux, Centre de Recherche cardio-thoracique de Bordeaux, U1045, CIC 1401, Bordeaux,

\section{Dan Elgrabli}

SAS Naor Innov, Courbevoie

\section{Toru Murayama}

Research Center for Gold Chemistry, Department of Applied Chemistry for Environment, Graduate School of Urban Environmental Sciences, Tokyo Metropolitan University, 1-1Minami-osawa, Hachioji, Tokyo 19

\section{Masatake Haruta}

Research Center for Gold Chemistry, Department of Applied Chemistry for Environment, Graduate School of Urban Environmental Sciences, Tokyo Metropolitan University, 1-1Minami-osawa, Hachioji, Tokyo 19

\section{Sophie Lanone}

Univ Paris Est Creteil, INSERM, IMRB, F-94010 Creteil

\section{Tamao Ishida}

Research Center for Gold Chemistry, Department of Applied Chemistry for Environment, Graduate School of Urban Environmental Sciences, Tokyo Metropolitan University, 1-1Minami-osawa, Hachioji, Tokyo 19 Jorge Boczkowski

Univ Paris Est Creteil, INSERM, IMRB, F-94010 Creteil

\section{Research Article}

Keywords: nanoparticles (NPs), anti-inflammatory effect

Posted Date: February 26th, 2021

DOl: https://doi.org/10.21203/rs.3.rs-237217/v1

License: (9) (1) This work is licensed under a Creative Commons Attribution 4.0 International License. Read Full License 
Version of Record: A version of this preprint was published at Scientific Reports on November 30th, 2021. See the published version at https://doi.org/10.1038/s41598-021-02419-4. 


\title{
Anti-inflammatory effect of gold nanoparticles supported on metal oxides
}

\author{
Takeshi Fujita $^{1,2^{*}}$, Maeva Zysman ${ }^{3,4,5}$, Dan Elgrabli ${ }^{3,6}$, Toru Murayama ${ }^{1}$, \\ Masatake Haruta ${ }^{1}$, Sophie Lanone ${ }^{3}$, Tamao Ishida ${ }^{1}$, Jorge Boczkowski ${ }^{3,7^{*}}$
}

(1) Research Center for Gold Chemistry, Department of Applied Chemistry for Environment, Graduate School of Urban Environmental Sciences, Tokyo Metropolitan University, 1-1Minami-osawa, Hachioji, Tokyo 192-0397, Japan

(2) Department of Applied Chemistry, School of Engineering, Tokyo University of Technology, 14011Katakura, Hachioji, Tokyo192-0982, Japan

(3) Univ Paris Est Creteil, INSERM, IMRB, F-94010 Creteil, France

(4) Univ Bordeaux, Centre de Recherche cardio-thoracique de Bordeaux, U1045, CIC 1401, Bordeaux, France.

(5) Service des Maladies Respiratoires, CHU Bordeaux, Bordeaux, France

(6) SAS Naor Innov, Courbevoie, France

(7) AP-HP, Hopital Henri Mondor, Antenne de Pneumologie, F-94010 Creteil, France

*corresponding authors : fujitatks@stf.teu.ac.jp, jorge.boczkowski@inserm.fr 


\section{ABSTRACT}

Gold $(\mathrm{Au}$ ) can be deposited as nanoparticles (NPs) smaller than $10 \mathrm{~nm}$ in diameter on a variety of metal oxide (MOx) NPs. Au/MOx NPs have high catalytic performance and selective oxidation capacity which could have implications in terms of biological activity, and more specifically in modulation of the inflammatory reaction. Therefore, the aim of this study was to examine the effect of $\mathrm{Au} / \mathrm{TiO}_{2}, \mathrm{Au} / \mathrm{ZrO}_{2}$ and $\mathrm{Au} / \mathrm{Ce} / \mathrm{O}_{2}$ on viability, phagocytic capacity and inflammatory profile (TNF- $\alpha$ and IL-1 $\beta$ secretion) of murine macrophages. The most important result of this study is an antiinflammatory effect of $\mathrm{Au} / \mathrm{MOx} \mathrm{NPs}$ depending on the MOx nature with particle internalization and no alteration of cell viability and phagocytosis. The effect was dependent on the MOx NPs chemical nature $\left(\mathrm{Au} / \mathrm{TiO}_{2}>\mathrm{Au} / \mathrm{ZrO}_{2}>\mathrm{Au} / \mathrm{CeO}_{2}\right.$ if we consider the number of cytokines whose concentration was reduced by the NPs), and on the inflammatory mediator considered. The effect of $\mathrm{Au} / \mathrm{TiO}_{2} \mathrm{NPs}$ was not related to Au NPs size (at least in the case of $\mathrm{Au} / \mathrm{TiO}_{2} \mathrm{NPs}$ in the range of 3-8 nm). To the best of our knowledge, this is the first demonstration of an anti-inflammatory effect of Au/MOx NPs. 


\section{INTRODUCTION}

Gold (Au) can be deposited as nanoparticles (NPs) smaller than $10 \mathrm{~nm}$ in diameter on a variety of metal oxide (MOx) NPs. Au/MOx NPs have attracted much attention due to their high catalytic performance for such as room temperature $\mathrm{CO}$ oxidation and selective oxidations in liquid phase ${ }^{12}$. The catalytic activity of Au strongly depends on the kind of support. For example, although $\mathrm{TiO}_{2}$ is almost inactive for $\mathrm{CO}$ oxidation, the deposition of $\mathrm{Au} \mathrm{NPs}$ onto $\mathrm{TiO}_{2}$ enables to catalyze $\mathrm{CO}$ oxidation at room temperature ${ }^{34}$.

These data in the field of heterogeneous catalysis have firmly established that deposition of Au on MOx NPs increases dramatically the intrinsic catalytic activity of these NPs and this could also be the case for the biological activity. For example, Menchon and co-workers ${ }^{5}$ reported that $\mathrm{Au} / \mathrm{CeO}_{2}$ exhibits antioxidant activity against reactive oxygen species (ROS) in Hep3B and HeLa cell related lines due to a peroxidase activity. Since the inflammatory reaction is highly dependent on oxidative stress $^{3}$, one can hypothesize that, in addition to their antioxidant properties, Au/MOx NPs can have anti-inflammatory effects. Such an effect could have important implications in terms of medical utilization of Au/MOx NPs. However, to the best of our knowledge no data on this effect is available in the current literature.

Therefore, in the present study we examined the effect of Au/MOx on cytotoxic and inflammatory response of macrophages, a key cell type involved in the inflammatory reaction. We used murine macrophages and investigated the roles of the size of Au NPs, the chemical nature of the supporting MOx NPs, and the kinetics of Au/MOx NPs interference with the inflammatory reaction.

\section{RESULTS}

\section{No cytotoxic effect of $\mathrm{Au} / \mathrm{TiO}_{2} \mathrm{NPs}$ on mouse macrophages}

Since physico-chemical properties of $\mathrm{Au} / \mathrm{TiO}_{2}$ have already been extensively described ${ }^{134}$, we have first compared biological effects of these $\mathrm{Au} / \mathrm{TiO}_{2} \mathrm{NPs}$ versus $\mathrm{TiO}_{2} \mathrm{NPs}$ on mouse peritoneal macrophages. No cytotoxicity was observed by either of MTT (Figure 1a and b) or LDH release assays (Figure $1 \mathrm{c}$ and d) for $\mathrm{TiO}_{2}$ and $\mathrm{Au} / \mathrm{TiO}_{2} \mathrm{NPs}$ regardless of the concentration ( 1 to $100 \mu \mathrm{g} \cdot \mathrm{ml}^{-1}$ ), the exposure time ( 24 and $48 \mathrm{~h}$ ) and the size of $\mathrm{Au} \mathrm{NPs}$. By contrast, $\mathrm{Ag} / \mathrm{TiO}_{2}$ and $\mathrm{Pt} / \mathrm{TiO}_{2}$ displayed significant cytotoxic effects in murine RAW 264.7 macrophages at $100 \mu \mathrm{g} \cdot \mathrm{ml}^{-1}$ as compared to $\mathrm{TiO}_{2}$, whereas $\mathrm{Au} / \mathrm{TiO}_{2}$ and $\mathrm{Pd} / \mathrm{TiO}_{2}$ did not show any cytotoxicity (Figure 2).

$\mathrm{TiO}_{2}$ and $\mathrm{Au} / \mathrm{TiO}_{2} \mathrm{NPs}\left(50 \mu \mathrm{g} \cdot \mathrm{ml}^{-1}, 6 \mathrm{~h}\right.$ incubation) significantly and similarly increased the phagocytosis of fluorescent beads by peritoneal macrophages, showing an absence of modulation of $\mathrm{TiO}_{2} \mathrm{NPs}$ induced macrophage activation by AuNPs (Figure 3). 


\section{$\mathrm{TiO}_{2}$ and $\mathrm{Au} / \mathrm{TiO}_{2} \mathrm{NP}$ are internalized in mouse peritoneal macrophages}

Cellular uptake and intracellular morphology upon $24 \mathrm{~h}$ exposure to $\mathrm{TiO}_{2}$ and $\mathrm{Au} / \mathrm{TiO}_{2} \mathrm{NPs}$ were investigated in ultrathin sections of resin-embedded cells using TEM.

$\mathrm{TiO}_{2} \mathrm{NPs}$ and $\mathrm{Au} / \mathrm{TiO}_{2} \mathrm{NPs}\left(50 \mu \mathrm{g} \cdot \mathrm{ml}^{-1}\right)$ were internalized in cells. The prevalent localization of NPs agglomerates was in cell vacuoles (Figure 4 a-c). In accordance with the previous paragraph showing a lack of cytotoxicity, no morphologic sign of cell damage was observed.

\section{No inflammation induced by $\mathrm{Au} / \mathrm{TiO}_{2} \mathrm{NPs}$}

Incubation of mouse peritoneal macrophages with $\mathrm{TiO}_{2} \mathrm{NPs}\left(50 \mu \mathrm{g} \cdot \mathrm{ml}^{-1}, 6 \mathrm{~h}\right)$, induced a significant increase in the concentration of TNF- $\alpha$ (Figure 5a) and IL-1 $\beta$ (Figure 5b), two main pro-inflammatory cytokines, in cell culture medium. This effect was not observed in the case of $\mathrm{Au} / \mathrm{TiO}_{2} \mathrm{NPs}$ without any significant difference between the size of Au NPs (Figure 5).

\section{$\mathrm{Au} / \mathrm{TiO}_{2} \mathrm{NPsattenuate} \mathrm{LPS}$-induced inflammation}

Having demonstrated that $\mathrm{Au} / \mathrm{TiO}_{2}$ NPs did not elicit an inflammatory reaction, we questioned whether $\mathrm{Au} / \mathrm{TiO}_{2} \mathrm{NPs}$ could blunt inflammation induced in a model of pathophysiological relevance, such as macrophages exposure to EscherichiaColi LPS. Au/TiO ${ }_{2}$ having 3 and $8 \mathrm{~nm}$ of Au NPs in diameters, abbreviated as $\mathrm{Au} 3 / \mathrm{TiO}_{2}$ and $\mathrm{Au} 8 / \mathrm{TiO}_{2}$, respectively, were used. Since no difference of anti-inflammatory effect was observed between $\mathrm{Au3} / \mathrm{TiO}_{2}$ and $\mathrm{Au} 8 / \mathrm{TiO}_{2}$, we investigated the effects of $\mathrm{Au} 3 / \mathrm{TiO}_{2} \mathrm{NPs}$ (referred to as $\mathrm{Au} / \mathrm{TiO}_{2}$ in the following experiments). Mouse peritoneal macrophages were incubated with culture media $6 \mathrm{~h}$ (control condition) or LPS $2 \mathrm{~h}$, and then the following $4 \mathrm{~h}$ with LPS alone or LPS plus $\mathrm{TiO}_{2}$ or $\mathrm{Au} / \mathrm{TiO}_{2}$. Taking into account the results presented in the previous paragraph, TNF- $\alpha$ and IL-1 $\beta$ cell culture supernatant concentrations were measured as a surrogate of the inflammatory reaction. As expected, incubation of cells with LPS for $2+4 \mathrm{~h}$ induced a significant increase as compared to the control condition ( $p<0.05$, Figures $6 a$ and $b$ ). Incubation of LPS followed by $\mathrm{TiO}_{2}$ NPs did not significantly modify the effect of LPS alone. By contrast, this last effect was significantly attenuated by macrophage incubation with $\mathrm{Au} / \mathrm{TiO}_{2} \mathrm{NPs}(p<0.05$, Figures $6 a$ and b). These results show that $\mathrm{Au} / \mathrm{TiO}_{2}$ can attenuate LPS induced inflammation, even when cells are incubated with these NPs after incubation with LPS.

\section{Effects of $\mathrm{Au} / \mathrm{ZrO}_{2}$ and $\mathrm{Au} / \mathrm{CeO}_{2} \mathrm{NPs}$ on LPS-induced inflammation}

After showing the anti-inflammatory effect of $\mathrm{Au} / \mathrm{TiO}_{2} \mathrm{NPs}$, we investigated if this effect was related to the chemical nature of the MOx NPs supports. To answer to this question, we examined the effect of Au NPs deposited on either $\mathrm{ZrO}_{2}$ or $\mathrm{CeO}_{2}$ NPs.

No effect was observed with $\mathrm{Au} / \mathrm{CeO}_{2}$ NPs, whereas $\mathrm{Au} / \mathrm{ZrO}_{2}$ NPs attenuated LPS-induced IL-1 $\beta$ production without any effect on TNF- $\alpha$ concentration (Figures $6 a$ and $b$ ). Therefore, we can 
conclude that Au/MOx NPs possess an anti-inflammatory effect which depends on the nature of the MOx NPs and on the inflammatory mediator examined.

\section{Is the anti-inflammatory effect of $\mathrm{Au} / \mathrm{MOx} \mathrm{NP}$ related to cytokines adsorption on their surface?}

We investigated the mechanisms underlining the anti-inflammatory effect of Au/MOx NPs. Since NPs adsorb different proteins on their surfaces ${ }^{6}$, we then investigated if the decreased concentration of LPS-induced TNF- $\alpha$ and IL-1 $\beta$ concentration observed with $\mathrm{Au} / \mathrm{TiO}_{2}$ and $\mathrm{Au} / \mathrm{ZrO}_{2}$ (only for IL-1 $\beta$ in this last case) was related to adsorption of these cytokines on these Au/MOx NPs. The results of these experiments showed that incubation of each one of these cytokines with the different Au/MOx NPs examined in this study did not change its respective concentration when compared to the MOx NPS without $\mathrm{Au}$ (Figure $7 \mathrm{a}$ and $\mathrm{b}$ ). This result excludes cytokines adsorption as a mechanism explaining the anti-inflammatory effect of $\mathrm{Au} / \mathrm{TiO}_{2}$ and $\mathrm{Au} / \mathrm{ZrO}_{2} \mathrm{NPs}$.

\section{Is the anti-inflammatory effect of $\mathrm{Au} / \mathrm{MOx} \mathrm{NP}$ related to their antioxidant properties?}

We then examined if the anti-inflammatory effect of $\mathrm{Au} / \mathrm{TiO}_{2}$ and $\mathrm{Au} / \mathrm{ZrO}_{2}$ was related to antioxidant properties, as demonstrated in other conditions ${ }^{78}$. To investigate this issue, we measured the effect of $\mathrm{Au} / \mathrm{MOx}$ NPs on intracellular reactive oxygen species (ROS) concentration. These experiments showed that intracellular ROS production induced by $\mathrm{Au} / \mathrm{TiO}$ and $\mathrm{Au} / \mathrm{ZrO}_{2} \mathrm{NPs}$ was smaller than that of $\mathrm{TiO}_{2}$ and $\mathrm{ZrO}_{2}$ respectively, demonstrating an antioxidant effect of these NPs (Table 1), in accordance with their (partial) anti-inflammatory effect. This effect was more important in the case of $\mathrm{Au} / \mathrm{ZrO}_{2}$ compared to $\mathrm{Au} / \mathrm{TiO}_{2}$ (mean reduction of $32 \%$ vs $11 \%$ compared to $\mathrm{ZrO}_{2}$ and $\mathrm{TiO}_{2}$ respectively). This effect could be involved in the anti-inflammatory effect described previously. Interestingly, levels of ROS were lower in cells exposed to $\mathrm{CeO}_{2}$ as compared to cells exposed to $\mathrm{TiO}_{2}$ and $\mathrm{ZrO}_{2}$, in accordance with antioxidant properties of $\mathrm{CeO}_{2}$ described previously ${ }^{9}$.

\section{DISCUSSION}

The most important result of this study is an anti-inflammatory effect of Au/MOx NPs depending on the MOx nature with particle internalization and no alteration of cell viability and phagocytosis. Interestingly, the lack of effect $\mathrm{Au} / \mathrm{TiO}_{2}$ on cell viability appears relatively specific for this combination of NPs, since $\mathrm{Ag} / \mathrm{TiO}_{2}$ and $\mathrm{Pt} / \mathrm{TiO}_{2}$ impaired macrophages viability. The effect of $\mathrm{Au} / \mathrm{TiO} \mathrm{O}_{2}$ NPs was not related to Au NPs size (at least in the case of $\mathrm{Au} / \mathrm{TiO}_{2} \mathrm{NPs}$ in the range of 3-8 nm) and was dependent on the MOx NPs chemical nature $\left(\mathrm{Au} / \mathrm{TiO}_{2}>\mathrm{Au} / \mathrm{ZrO}_{2}>\mathrm{Au} / \mathrm{CeO}_{2}\right.$ if we consider the number of cytokines whose concentration was reduced by the NPs) and on the inflammatory mediator considered. To the best of our knowledge, this is the first demonstration that $\mathrm{Au} / \mathrm{MOx}$ present anti-inflammatory properties. 
The effect of Au/MOx could be related to anti-inflammatory properties of Au NPs per se. Indeed, gold colloids have been thought to cure various diseases for many centuries, and recent studies have demonstrated that this effect is mediated by inhibition of NF-KB activation ${ }^{10}$. Different studies showed a similar effect in the case of Au NPs in vitro and in vivo, this effect being usually mediated by antioxidant properties ${ }^{11,12,13,14,15}$. However, other studies showed opposite results. For example, $\mathrm{Ng}$ and coworkers ${ }^{16}$ showed that incubation of human bronchial epithelial cells with $50 \mu \mathrm{g} \cdot \mathrm{ml}^{-1}$ of $20 \mathrm{~nm}$ Au NPs activated NF- $\kappa$ B in bronchial epithelial cells. Close results were shown in other cell types ${ }^{17,18}$. Therefore, an anti-inflammatory effect of Au NPs per se seems not a univocal mechanism explaining the anti-inflammatory effect of Au/MOx NPs. Moreover, attributing our results to the biological activity of Au NPs is questionable since most of the studies showing an effect of Au NPs on inflammation examined concentrations far above the ones to whom cells were exposed in the present study, taking into account that Au NPs represented only $1 \%$ of the mass of Au/MOx.

Adsorption of TNF- $\alpha$ and IL-1 $\beta$ on Au/MOx surface could also explain their different antiinflammatory activity. Indeed, NPs, including Au NPs, can adsorb different molecules on their surface, resulting in their inactivation and reduction in their concentration in the medium ${ }^{19}$. However, this mechanism seems unlikely in the present study since we did not observe any significant difference in TNF- $\alpha$ and IL-1 $\beta$ levels when these cytokines were incubated with $\mathrm{TiO}_{2}$ or $\mathrm{ZrO}_{2} \mathrm{NPs}$ and their respective Au counterparts.

Finally, the differences in the anti-inflammatory effect of Au/MOx NPs could be related to their different antioxidant properties. However, the anti-inflammatory effect of Au/MOx NPs was not paralleled by the intracellular antioxidant properties since both $\mathrm{Au} / \mathrm{TiO}_{2}$ and $\mathrm{Au} / \mathrm{ZrO}_{2} \mathrm{NPs}$ reduced intracellular ROS concentration (with a more important effect of $\mathrm{Au} / \mathrm{ZrO}_{2}$ than $\mathrm{Au} / \mathrm{TiO}_{2}$ ) whereas only $\mathrm{Au} / \mathrm{TiO}_{2}$ attenuated both TNF- $\alpha$ and IL-1 $\beta$ induction. Moreover, the absence of an anti-inflammatory effect of $\mathrm{Au} / \mathrm{CeO}_{2}$ was paralleled by an absence of an antioxidant effect of this NP as compared to $\mathrm{CeO}_{2}$ NPs. Interestingly, in concordance with different studies, $\mathrm{CeO}_{2} \mathrm{NPs}$ exerted an antioxidant effect as compared to $\mathrm{TiO}_{2}$ and $\mathrm{ZrO}_{2} \mathrm{NPs}$ (Table 1), but this effect was not accompanied by an antiinflammatory effect. Collectively, these data suggest that in contrast with our initial hypothesis, an antioxidant effect does not appear as a mechanism globally explaining the effect of $\mathrm{Au} / \mathrm{TiO}_{2}$ and $\mathrm{Au} / \mathrm{ZrO}_{2}$. Indeed, an antioxidant effect could potentially explain the effect of $\mathrm{Au} / \mathrm{TiO}_{2} \mathrm{NPs}$ but not the one of $\mathrm{Au} / \mathrm{ZrO}_{2} \mathrm{NPs}$ because these last NPs had showed an antioxidant effect similar to $\mathrm{Au} / \mathrm{TiO}_{2}$ but attenuated only IL-1 $\beta$ induction. Consequently, the effect of $\mathrm{Au} / \mathrm{ZrO}_{2}$ appears to depend on pathways inhibiting IL-1 $\beta$ but not TNF- $\alpha$ expression. 
Numerous mechanisms control the production and activity of IL-1 $\beta$, including the processing of the 31-kDa, inactive IL-1 $\beta$ precursor into the bioactive, 17-kDa cytokine via intracellular protein complexes termed the inflammasomes ${ }^{20}$.The most intensely studied inflammasome is the NLRP3 inflammasome. Various stimuli activate the NLRP3inflammasome: bacterial structures such as muramyl dipeptide or LPS, bacterial RNA, $\beta$-glucan, double-stranded RNA, etc. The release of ROS has been repeatedly reported to mediate NLRP3 inflammasome activation by various stimuli, including LPS, but this has been surrounded by controversy ${ }^{21}$. Other proposed mechanisms responsible for NLRP3 inflammasome activation are i) translocation to mitochondria ${ }^{22}$, ii) release of mitochondrial DNA or cardiolipin ${ }^{23}$, iii) release of lysosomal cathepsins into the cytoplasm ${ }^{24}$, or iv) calciumdependent phospholipase 2 activation ${ }^{20}$. Interference with one or several mechanisms could explain attenuation of LPS-induced IL-1 $\beta$ expression by $\mathrm{Au} / \mathrm{ZrO}_{2}$ NPs. However, investigating these possibilities needs further studies.

This study presents 2 main limitations. First, we only measured 2 cytokines as a surrogate of inflammatory markers. Even if these cytokines are broadly representative of the inflammatory reaction and are one of the very early ones in the inflammatory cascade, and we investigate primary murine macrophages (a key cell involved in inflammation), a wider analysis of mediators of this reaction is necessary to validate the present results. Second, we investigated only 3 MOx NPs supports. Although we choose supports widely characterized in terms of catalytic properties when combined with Au NPs, investigating a broader panel of MOx could allow a better characterizing the anti-inflammatory properties of Au/MOx NPs. It has to be noted, however, that we compared cytotoxicity of $\mathrm{Au} / \mathrm{TiO}_{2}$ with other metallic NPs deposited on $\mathrm{TiO}_{2}(\mathrm{Ag}, \mathrm{Pt}$ and $\mathrm{Pd}$ ) and we showed that only $\mathrm{Au} / \mathrm{TiO}_{2}$ and $\mathrm{Pd} / \mathrm{TiO}_{2}$ did not impaired cell viability at the concentrations examined, providing an additional argument for the beneficial effects of $\mathrm{Au} / \mathrm{TiO}_{2} \mathrm{NPs}$.

In conclusion, this study showed that $\mathrm{Au} / \mathrm{MOx}$ possess anti-inflammatory properties in macrophages. This effect could have potential applications in the clinical setting since it does not interfere with physiological parameters of these cells such as viability and phagocytosis.

\section{METHODS}

\section{Nanoparticles preparation}

Au NPs with two different mean diameters $\left(3\right.$ and $8 \mathrm{~nm}$ ) supported on pristine $\mathrm{TiO}_{2} \mathrm{NPs}$ (Nippon Aerosil Co., Ltd., AEROXIDE P25) were prepared, termed $\mathrm{Au} 3 / \mathrm{TiO}_{2}$ and $\mathrm{Au} 8 / \mathrm{TiO}_{2}$, respectively. $\mathrm{Au} 3 / \mathrm{TiO}_{2}$ were prepared by deposition-precipitation ${ }^{3}$ followed by calcination at $300{ }^{\circ} \mathrm{C}$ for $4 \mathrm{~h}$. $\mathrm{Au} 8 / \mathrm{TiO}_{2}$ was prepared by solid grinding with dimethyl $\mathrm{Au}$ (III) acetylacetonate and by calcination at $300{ }^{\circ} \mathrm{C}^{25} . \mathrm{Au} / \mathrm{ZrO}_{2}$ and $\mathrm{Au} / \mathrm{CeO}_{2}$ were purchased from Haruta Gold Inc ${ }^{\complement}$. The primary particle sizes of 
$\mathrm{Au} 3 / \mathrm{TiO}_{2}, \mathrm{Au} / \mathrm{ZrO}_{2}$, and $\mathrm{Au} / \mathrm{CeO}_{2}$ were $26 \mathrm{~nm}, 11 \mathrm{~nm}$, and $7.3 \mathrm{~nm}$ respectively, estimated from their specific surface areas of the MOx NPs. The secondary particle sizes of $\mathrm{Au} 3 / \mathrm{TiO}_{2}, \mathrm{Au} / \mathrm{ZrO}_{2}$, and $\mathrm{Au} / \mathrm{CeO}_{2}$ were $5.5 \mu \mathrm{m}, 0.9 \mu \mathrm{m}$, and $3.6 \mu \mathrm{m}$ respectively, determined by dynamic light scattering method. Using atomic absorption spectroscopy, the actual Au loadings for $\mathrm{Au} 3 / \mathrm{TiO}_{2}, \mathrm{Au} 8 / \mathrm{TiO}_{2}$, $\mathrm{Au} / \mathrm{ZrO}_{2}$, and $\mathrm{Au} / \mathrm{CeO}_{2}$ were $0.96,1.18,0.97$, and $0.96 \mathrm{wt} \%$, respectively. The mean diameters of $\mathrm{Au}$ NPs were estimated by high-angle annular dark-field scanning transmission electron microscopy (HAADF-STEM) to be $3.3 \pm 1.4 \mathrm{~nm}$ for $\mathrm{Au} 3 / \mathrm{TiO}_{2}, 7.8 \pm 2.7 \mathrm{~nm}$ for $\mathrm{Au} 8 / \mathrm{TiO}_{2}$, and $3.3 \pm 1.8 \mathrm{~nm}$ for $\mathrm{Au} / \mathrm{ZrO}_{2}$. In the case of $\mathrm{Au} / \mathrm{CeO}_{2}$, it was difficult to observe Au NPs because Au was mostly deposited as single atoms and the atomic number of $\mathrm{Ce}$ is close to that of $\mathrm{Au}$.

Metal NPs other than $\mathrm{Au}$, namely $\mathrm{Ag}, \mathrm{Pt}, \mathrm{Pd}$, supported on $\mathrm{TiO}_{2}$ (loading: $1 \mathrm{wt} \%$ ) were prepared by impregnation. $\mathrm{TiO}_{2}$ was suspended in aqueous $\mathrm{AgNO}_{3}, \mathrm{H}_{2} \mathrm{PtCl}_{6} \cdot 6 \mathrm{H}_{2} \mathrm{O}$, or $\mathrm{PdCl}_{2}$, followed by evaporation to dryness at $70{ }^{\circ} \mathrm{C}$. The remaining paste was reduced in $10 \% \mathrm{H}_{2}$ in $\mathrm{N}_{2}$ at $300{ }^{\circ} \mathrm{C}$ for $4 \mathrm{~h}$.

\section{Cells isolation and incubation with nanoparticles}

Peritoneal macrophages and macrophages from the RAW 264.7 cell line were used in the different experiments.

Peritoneal macrophages.C57BL/6 mice were injected intraperitoneally with $1 \mathrm{ml}$ of $3 \%$ Brewer thioglycollate (Sigma-Aldrich, B2551). After 96 h, peritoneal cells were harvested by lavage with $0.67 \%$ phosphate buffered saline (PBS). After a soft centrifugation, cells were maintained in Dulbecco's modified Eagle medium (DMEM) 4,5 g. L $^{-1}$ glucose supplemented with $10 \%$ fetal calf serum (FCS)and $1 \%$ penicillin and $1 \%$ streptomycin. Then mice peritoneal macrophagic cells were exposed for 6-48 h to 1-100 $\mu \mathrm{g} / \mathrm{mL}$ particles of $\mathrm{Au} / \mathrm{TiO}_{2}, \mathrm{Au} / \mathrm{ZrO}_{2}, \mathrm{Au} / \mathrm{CeO}_{2}$, and $\mathrm{MOx}$ alone.

RAW 264.7 macrophages. The RAW 264.7 cells were cultured using a medium having the same composition as above and were exposed for $24 \mathrm{~h}$ to $1-100 \mu \mathrm{g} / \mathrm{ml}$ nanoparticles of $\mathrm{Au} / \mathrm{TiO}_{2}, \mathrm{Ag} / \mathrm{TiO}_{2}$, $\mathrm{Pt} / \mathrm{TiO}_{2}, \mathrm{Pd} / \mathrm{TiO}_{2}$ and $\mathrm{TiO}_{2}$.

\section{Cellular viability}

The viability of cells was measured by 3-[4,5-dimethylthiazol-2-yl]-2,5 diphenyl tetrazolium bromide (MTT) assay, 2-(4-iodophenyl)-3-(4-nitrophenyl)-5-(2,4-disulfophenyl)-2H-tetrazolium, monosodium salt (WST-1) assay, and the quantification of the release of lactate dehydrogenase (LDH).

\section{Phagocytosis assay}

RAW 264.7 cells (ATCC) were exposed to $50 \mu \mathrm{g} \cdot \mathrm{mL}^{-1} \mathrm{CNT}$ for $6 \mathrm{~h}$, together with Latex beads-rabbit IgG-FITC complex, as per the manufacturer's instructions (Phagocytosis assay Kit; Cayman Chemical, $500,290)$. Fluorescence was measured at $\lambda$ exc $=485 \mathrm{~nm}$, and $\lambda$ emi $=535 \mathrm{~nm}^{26}$.

Transmission electron microscopy (TEM) 
Macrophages submitted to different exposure were fixed overnight at $4{ }^{\circ} \mathrm{C}$ using TEM-grade fixative solution of $2 \%$ formaldehyde and $2.5 \%$ glutaraldehyde in $0.1 \mathrm{M}$ sodium cacodylate buffer, $\mathrm{pH} 7.4$. The samples were washed and stored in $0.1 \mathrm{M}$ sodium cacodylate buffer and kept at $4{ }^{\circ} \mathrm{C}$ until processing. Sample embedding was performed in epoxy resin according a standard protocol.

\section{Inflammatory responses}

Inflammatory response was evaluated by the quantification of cytokines such as tumor necrosis factor (TNF)- $\alpha$ and interleukin (IL)-1 $\beta$ in cell supernatant, measured by enzyme-linked immunosorbent assay (ELISA).

\section{Measurement of oxidative stress by DCFH-DA assay}

Endogenous ROS were quantified by oxidation of $2^{\prime}, 7^{\prime}$-dichlorofluorescin diacetate (DCFH-DA) into $2^{\prime}, 7^{\prime}$-dichlorofluorescin (Sigma, Saint Quentin Fallavier, France). Briefly, cells were cultivated in six-well culture plates and treated with $50 \mu \mathrm{g}$. $\mathrm{ml}^{-1} \mathrm{NPs}$. Cells were also treated with $250 \mu \mathrm{M} \mathrm{H} \mathrm{O}_{2}$ as a positive control (data not shown). Cells were incubated with $20 \mu \mathrm{M} \mathrm{DCFH-DA}$ for $30 \mathrm{~min}$ at $37^{\circ} \mathrm{C}$ and fluorescence recorded for $90 \mathrm{~min}$. Results were expressed as the mean ratio of fluorescence recorded every 15 min during the 90 min period.

\section{Measurement of TNF- $\alpha$ and IL-1 $\beta$ adsorption to NPs}

Adsorption of TNF- $\alpha$ and IL-1 $\beta$ adsorption to NPs was performed by ELISA as described previously described ${ }^{27}$.

\section{Statistical Analysis}

JASP software (version 0.11.1, https://jasp-stats.org/) was used to analyze quantitative data. Nonparametric ANOVA was used to compare multiple groups. Paired comparisons with Mann-Whitney test were performed if the differences using ANOVA were statistically significantly different. Data were presented as mean values \pm standard error of the mean (SEM), and results were considered statistically significant if $p<0.05$.

\section{Study approval for animal experiments}

The Institutional Animal Care and Use Committee approved experimental procedures on mice (Autorisation De Projet Utilisant Des Animaux A Des Fins Scientifiques APAFIS authorization \#149142018042515599016). All experiments were carried out in accordance with relevant guidelines and regulations. The study was carried out in compliance with the ARRIVE guidelines.

\section{DATA AVAILABILITY}

The datasets used and/or analyzed during the current study are available from the corresponding author on reasonable request. 


\section{REFERENCES}

1 Haruta, M. When gold is not noble: catalysis by nanoparticles. Chem Rec3, 75-87, doi:10.1002/tcr.10053 (2003).

2 Taketoshi, A. \& Haruta, M. Size- and Structure-specificity in Catalysis by Gold Clusters. Chem Lett43, 380-387, doi:10.1246/cl.131232 (2014).

3 Haruta, M. et al. Low-Temperature Oxidation of Co over Gold Supported on Tio2, AlphaFe2o3, and Co3o4. J Catal144, 175-192, doi:DOI 10.1006/jcat.1993.1322 (1993).

4 Ishida, T., Murayama, T., Taketoshi, A. \& Haruta, M. Importance of Size and Contact Structure of Gold Nanoparticles for the Genesis of Unique Catalytic Processes. Chem Rev120, 464-525, doi:10.1021/acs.chemrev.9b00551 (2020).

5 Menchon, C. et al.Gold nanoparticles supported on nanoparticulate ceria as a powerful agent against intracellular oxidative stress. Smal/8, 1895-1903, doi:10.1002/smll.201102255 (2012). Lundqvist, M. et al. Nanoparticle size and surface properties determine the protein corona with possible implications for biological impacts. Proc Natl Acad Sci U S A105, 14265-14270, doi:0805135105 10.1073/pnas.0805135105 (2008).

7 Lucchetti, B. F. C. et al. Metabolic syndrome agravates cardiovascular, oxidative and inflammatory dysfunction during the acute phase of Trypanosoma cruzi infection in mice. Sci Rep9, 18885, doi:10.1038/s41598-019-55363-9 (2019).

8 Scalavino, V. et al. miR-369-3p modulates inducible nitric oxide synthase and is involved in regulation of chronic inflammatory response. Sci Rep10, 15942, doi:10.1038/s41598-02072991-8 (2020).

9 Pezzini, I. et al. Cerium oxide nanoparticles: the regenerative redox machine in bioenergetic imbalance. Nanomedicine (Lond)12, 403-416, doi:10.2217/nnm-2016-0342 (2017).

10 Narayanan, K. B. \& Park, H. H. Pleiotropic functions of antioxidant nanoparticles for longevity and medicine. Adv Colloid Interface Sci201-202, 30-42, doi:10.1016/j.cis.2013.10.008 (2013).

11 Zhu, S. et al.Orally administered gold nanoparticles protect against colitis by attenuating Tolllike receptor 4- and reactive oxygen/nitrogen species-mediated inflammatory responses but could induce gut dysbiosis in mice. J Nanobiotechnology16, 86, doi:10.1186/s12951-0180415-5 (2018).

12 Lai, T. H., Shieh, J. M., Tsou, C. J. \& Wu, W. B. Gold nanoparticles induce heme oxygenase-1 expression through Nrf2 activation and Bach1 export in human vascular endothelial cells. Int J Nanomedicine10, 5925-5939, doi:10.2147/IJN.S88514 (2015).

13 Pereira, D. V. et al. Effects of gold nanoparticles on endotoxin-induced uveitis in rats. Invest Ophthalmol Vis Sci53, 8036-8041, doi:10.1167/iovs.12-10743 (2012).

14 Haupenthal, D. et al.Effects of chronic treatment with gold nanoparticles on inflammatory responses and oxidative stress in Mdx mice. J Drug Target, 1-9, doi:10.1080/1061186X.2019.1613408 (2019).

15 Taratummarat, S. et al. Gold nanoparticles attenuates bacterial sepsis in cecal ligation and puncture mouse model through the induction of $M 2$ macrophage polarization. $B M C$ Microbio/18, 85, doi:10.1186/s12866-018-1227-3 (2018).

$16 \mathrm{Ng}, \mathrm{C}$. T. et al. Gold nanoparticles induce serum amyloid A 1-Toll-like receptor 2 mediated NFkB signaling in lung cells in vitro. Chem Biol Interact289, 81-89, doi:10.1016/j.cbi.2018.04.022 (2018).

17 Khan, H. A., Abdelhalim, M. A., Alhomida, A. S. \& Al Ayed, M. S. Transient increase in IL1 beta, IL-6 and TNF-alpha gene expression in rat liver exposed to gold nanoparticles. Genet Mol Res12, 5851-5857, doi:10.4238/2013.November.22.12 (2013).

$18 \mathrm{Li}, \mathrm{Y}$. et al. Bacterial endotoxin (lipopolysaccharide) binds to the surface of gold nanoparticles, interferes with biocorona formation and induces human monocyte 
doi:10.1080/17435390.2017.1401142 (2017).

19 Mukherjee, P. et al. Antiangiogenic properties of gold nanoparticles. Clin Cancer Res11, 35303534, doi:10.1158/1078-0432.CCR-04-2482 (2005).

20 Lamkanfi, M. \& Dixit, V. M. Mechanisms and functions of inflammasomes. Cell157, 10131022, doi:10.1016/j.cell.2014.04.007 (2014).

21 Netea, M. G., van de Veerdonk, F. L., van der Meer, J. W., Dinarello, C. A. \& Joosten, L. A. Inflammasome-independent regulation of IL-1-family cytokines. Annu Rev Immuno/33, 49-77, doi:10.1146/annurev-immunol-032414-112306 (2015).

22 Subramanian, N., Natarajan, K., Clatworthy, M. R., Wang, Z. \& Germain, R. N. The adaptor MAVS promotes NLRP3 mitochondrial localization and inflammasome activation. Cell153, 348-361, doi:10.1016/j.cell.2013.02.054 (2013).

23 Nakahira, K. et al. Autophagy proteins regulate innate immune responses by inhibiting the release of mitochondrial DNA mediated by the NALP3 inflammasome. Nat Immuno/12, 222230, doi:10.1038/ni.1980 (2011).

24 Duewell, P. et al. NLRP3 inflammasomes are required for atherogenesis and activated by cholesterol crystals. Nature464, 1357-1361, doi:10.1038/nature08938 (2010).

25 Ishida, T. et al. Influence of the Support and the Size of Gold Clusters on Catalytic Activity for Glucose Oxidation. Angew Chem Int Edit47, 9265-9268, doi:10.1002/anie.200802845 (2008).

26 Cohignac, V. et al. Carbon nanotubes, but not spherical nanoparticles, block autophagy by a shape-related targeting of lysosomes in murine macrophages. Autophagy14, 1323-1334, doi:10.1080/15548627.2018.1474993 (2018).

27 Bussy, C. et al. Critical role of surface chemical modifications induced by length shortening on multi-walled carbon nanotubes-induced toxicity. Part Fibre Toxicol9, 46, doi:10.1186/17438977-9-46 (2012). 


\section{ACKNOWLEDGMENTS}

\section{AUTHORS CONTRIBUTION}

TF prepared and analyzed NPs, performed chemical experiments and critically reviewed the manuscript. TF, MZ and DE performed biological experiments. TM, MH, and SL critically reviewed the manuscript and worked on its final elaboration. TI contributed to the design of the study, critically reviewed the manuscript and worked on its final elaboration. JB designed the study and wrote the first and final drafts of the manuscript.

All authors approved the final version of the manuscript.

\section{COMPETING INTERESTS}

The authors declare no competing interests. 


\section{Figure Legends}

Figure 1. Cytotoxicity of $\mathrm{Au}$ nanoparticles (NPs) with two different diameters ( 3 and $8 \mathrm{~nm}$ respectively) supported on pristine $\mathrm{TiO}_{2}\left(\mathrm{Au} 3 / \mathrm{TiO}_{2}\right.$ and $\mathrm{Au} / \mathrm{TiO} \mathrm{Ti}_{2}$ respectively) and $\mathrm{TiO}_{2} \mathrm{NPs}$ alone on mouse peritoneal macrophages. Cell viability was measured using the MTT assay (panels a and b) and LDH relargage (panels $\mathrm{c}$ and d) after 24 and $48 \mathrm{~h}$ incubation (panels a and $\mathrm{c}$ and b and d respectively). Data are expressed as percentage of control condition (without NPs, $100 \%$ is the reference value) and are represented as mean \pm SEM of 6 independent experiments. Positive controls are doxorubicine (DOXO, 1, 5 and $10 \mu \mathrm{g} \cdot \mathrm{ml}^{-1}$ ) and TritonX-100 (10 vol. \%). ${ }^{*}$ significantly different from control $(p<0.05)$.

Figure 2. Cytotoxicity of $\mathrm{Au}, \mathrm{Ag}, \mathrm{Pt}, \mathrm{Pd}$ NPs supported on pristine $\mathrm{TiO}_{2} \mathrm{NPs}$ and pristine $\mathrm{TiO}_{2} \mathrm{NPs}$ alone on murine RAW 264.7 macrophages. Cell viability was measured using the WST-1 assay after $24 \mathrm{~h}$ incubation. Data are expressed as percentage of control condition (without NPs, $100 \%$ is the reference value) and are represented as mean \pm SEM of 6 independent experiments. Positive control is cisplatin $\left(1,5\right.$ and $\left.10 \mu \mathrm{g} \cdot \mathrm{ml}^{-1}\right)$. ${ }^{*}$ significantly different from control $(p<0.05)$, \# significantly different from control $(p<0.01)$

Figure 3.Effect of $\mathrm{Au} 3 / \mathrm{TiO}_{2}, \mathrm{Au} 8 / \mathrm{TiO}_{2}$ and $\mathrm{TiO}_{2} \mathrm{NPs}\left(50 \mu \mathrm{g} \cdot \mathrm{ml}^{-1}, 6 \mathrm{~h}\right.$ incubation) on phagocytosis of fluorescent beads by mouse peritoneal macrophages. Data are expressed as arbitrary units (AU) of fluorescence intensity and are represented as mean \pm SEM of 6 independent experiments. * significantly different from control $(p<0.05)$.

Figure 4. Transmission electron microscopy views of mouse peritoneal macrophages incubated $24 \mathrm{~h}$ with $50 \mu \mathrm{g} \cdot \mathrm{ml}^{-1}$ of $\mathrm{Au} 3 / \mathrm{TiO}_{2}, \mathrm{Au} 8 / \mathrm{TiO}_{2}$ and $\mathrm{TiO}_{2} \mathrm{NPs}$.

The scale bar in images in column a is 2 microns, and in columns b and c is 0.2 microns. As observed in the images, the prevalent localization of NPs agglomerates was in cell vacuoles. No morphologic sign of cell damage was observed.

Figure 5. Effect of $\mathrm{Au} 3 / \mathrm{TiO}_{2}, \mathrm{Au} 8 / \mathrm{TiO}_{2}$ and $\mathrm{TiO}_{2} \mathrm{NPs}\left(50 \mu \mathrm{g} \cdot \mathrm{ml}^{-1}, 6 \mathrm{~h}\right.$ incubation) on TNF- $\alpha$ and IL-1 $\beta$ secretion by mouse peritoneal macrophages (panels $a$ and $b$ respectively). Data are expressed as picograms $/ \mathrm{ml}$ in cell culture medium and are represented as mean \pm SEM of 6 independent experiments. " significantly different from control $(p<0.01)$

Figure 6. Effect of Au deposited on different metal oxide NPs on LPS induced TNF- $\alpha$ and IL$1 \beta$ secretion by mouse peritoneal macrophages (Panels $\mathrm{a}$ and $\mathrm{b}$ respectively). Cells were incubated with culture media $6 \mathrm{~h}$ (control condition, $\mathrm{C}$ ) or LPS $2 \mathrm{~h}$, and then the following $4 \mathrm{~h}$ with LPS alone or LPS plus the different NPs $\left(50 \mu \mathrm{g} . \mathrm{ml}^{-1}\right) .{ }^{*}$ significantly different from $\mathrm{C}(p<0.05),{ }^{* *}$ significantly different from LPS $2 \mathrm{~h}-\mathrm{TiO}_{2} 4 \mathrm{~h}(p<0.05)$, \& significantly different from LPS $2 \mathrm{~h}-\mathrm{ZrO}_{2} 4 \mathrm{~h}(p<0.05)$ 
Figure 7. TNF- $\alpha$ and IL-1 $\beta$ adsorption on Au deposited on different metal oxide NPs. NPs (50 $\left.\mu \mathrm{g} \cdot \mathrm{ml}^{-1}\right)$ were incubated during $6 \mathrm{~h}$ with TNF- $\alpha\left(150 \mathrm{pg} \cdot \mathrm{ml}^{-1}\right)$ and IL-1 $\beta\left(100 \mathrm{pg} \cdot \mathrm{ml}^{-1}\right)$ in culture media, then the cytokines were quantified in the media after centrifugation. 
Table 1

\begin{tabular}{ccc} 
Nanoparticle & Mean values \pm SEM & Statistical significance \\
\hline $\mathrm{Au} / \mathrm{TiO}_{2}$ & $12068 \pm 499$ & $*$ \\
$\mathrm{TiO}_{2}$ & $13547 \pm 340$ & \\
$\mathrm{Au} / \mathrm{ZrO}_{2}$ & $9170 \pm 109$ & $* *$ \\
$\mathrm{ZrO}$ & $13538 \pm 129$ & \\
$\mathrm{Au} / \mathrm{CeO}_{2}$ & $12743 \pm 340$ & \\
$\mathrm{CeO}_{2}$ & $12583 \pm 255$ & $\#$
\end{tabular}

Reactive oxygen species (ROS) production in RAW 264.7 cells after expositions to different NPs ( $n=7$ ). The final concentration of NPs was $50 \mu \mathrm{g} \cdot \mathrm{ml}^{-1}$. Amounts of ROS production were evaluated by the $\mathrm{CM}_{2}$-DCFDA. $* p<0.05$ vs $\mathrm{TiO}_{2}, * * p<0.01$ vs $\mathrm{ZrO}_{2}, \# p<0.05$ vs $\mathrm{TiO}_{2}$ and $\mathrm{ZrO}_{2}$. 
a

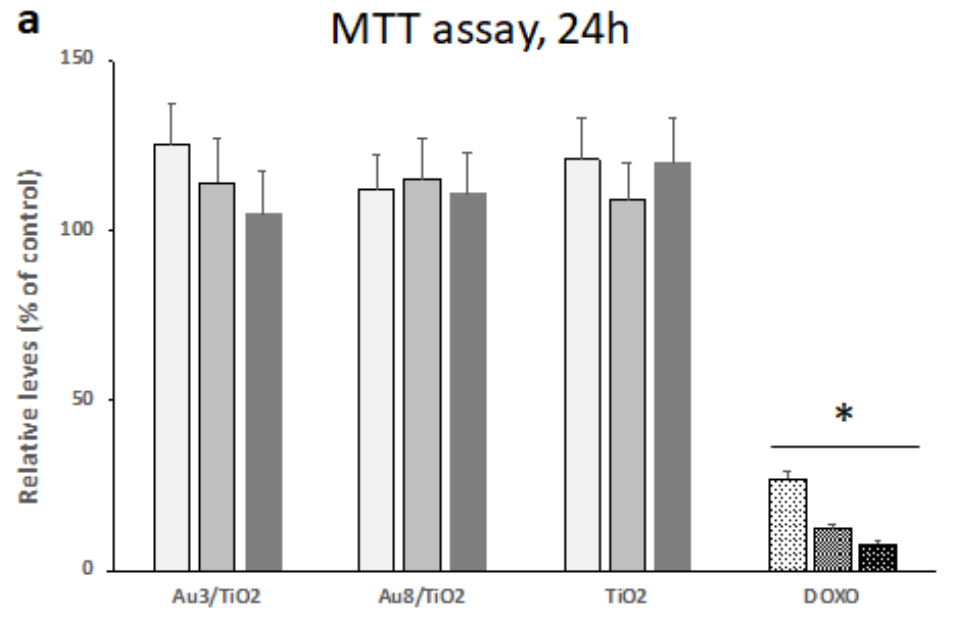

C

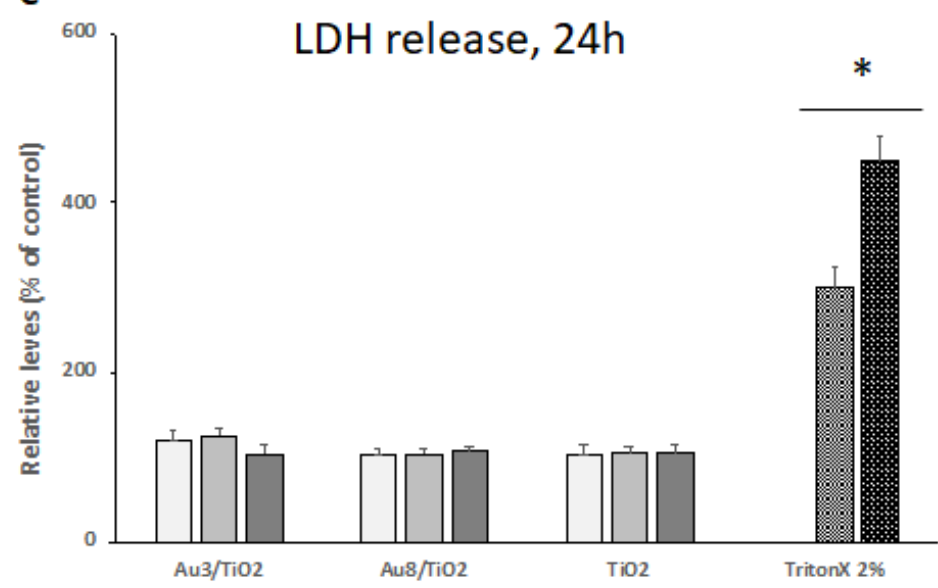

b
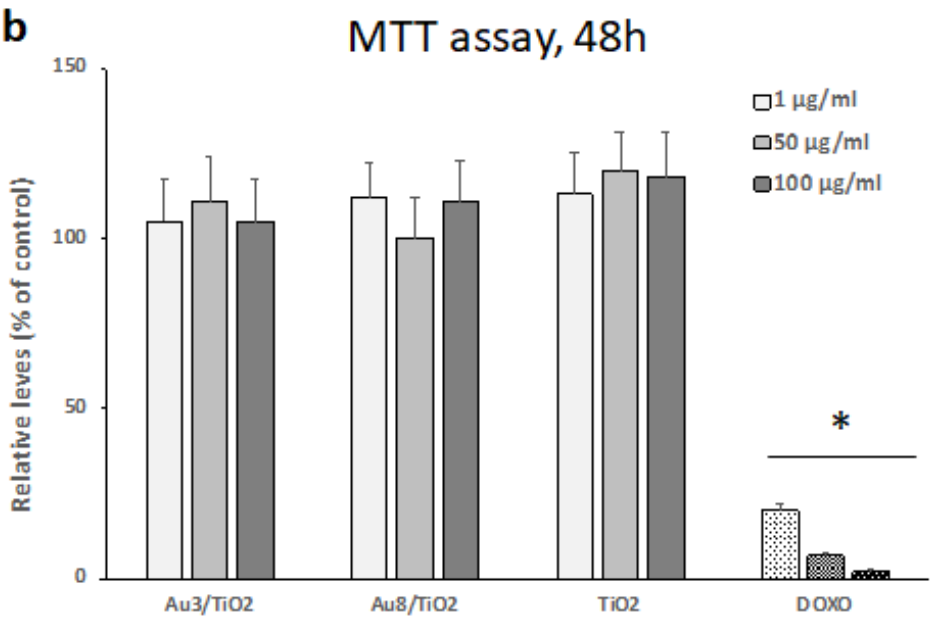

d

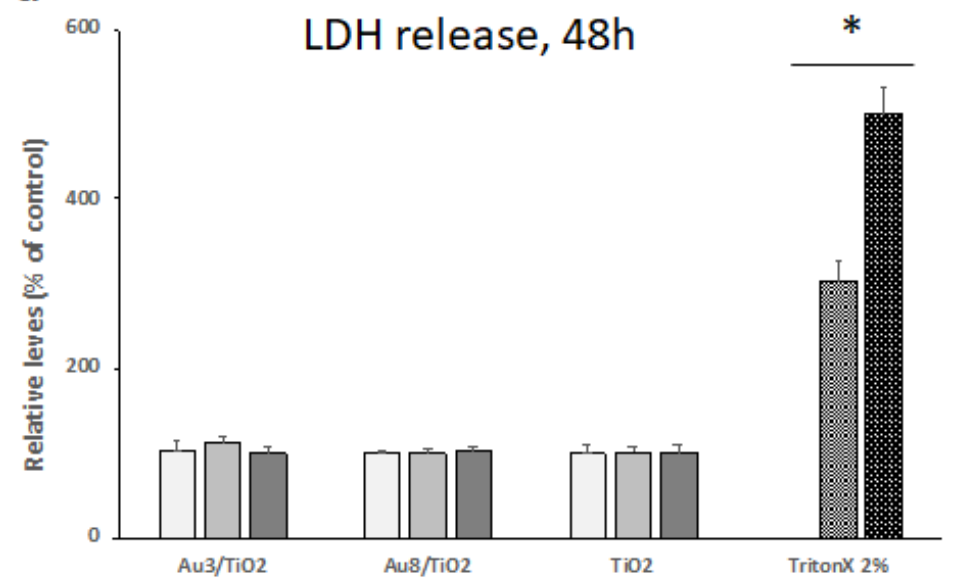

Figure 1

Cytotoxicity of Au nanoparticles (NPs) with two different diameters (3 and $8 \mathrm{~nm}$ respectively) supported on pristine TiO2 (Au3/TiO2 and Au8/TiO2 respectively) and TiO2 NPs alone on mouse peritoneal macrophages. Cell viability was measured using the MTT assay (panels a and b) and LDH relargage (panels $\mathrm{c}$ and $\mathrm{d}$ ) after 24 and 48h incubation (panels a and $\mathrm{c}$ and b and $\mathrm{d}$ respectively). Data are expressed as percentage of control condition (without NPs, $100 \%$ is the reference value) and are represented as mean \pm SEM of 6 independent experiments. Positive controls are doxorubicine (DOXO, 1, 5 and $10 \mu \mathrm{g} . \mathrm{ml}-1)$ and TritonX-100 (10 vol. \%). * significantly different from control $(p<0.05)$. 


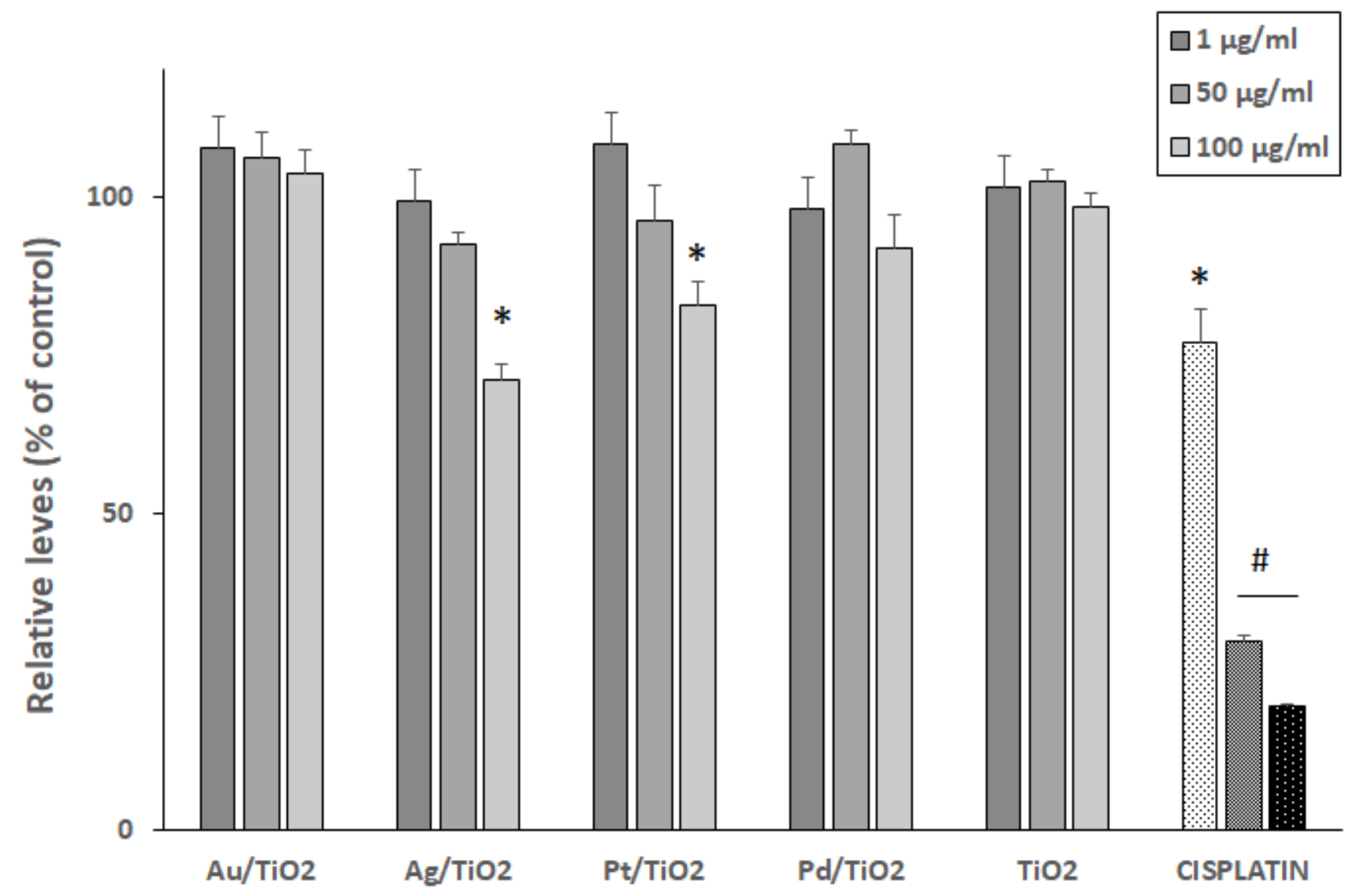

Figure 2

Cytotoxicity of Au, Ag, Pt, Pd NPs supported on pristine TiO2 NPs and pristine TiO2 NPs alone on murine RAW 264.7 macrophages. Cell viability was measured using the WST-1 assay after $24 \mathrm{~h}$ incubation. Data are expressed as percentage of control condition (without NPs, $100 \%$ is the reference value) and are represented as mean \pm SEM of 6 independent experiments. Positive control is cisplatin $(1,5$ and $10 \mu \mathrm{g} . \mathrm{ml}-$ $1)$. * significantly different from control $(p<0.05)$, \# significantly different from control $(p<0.01)$ 


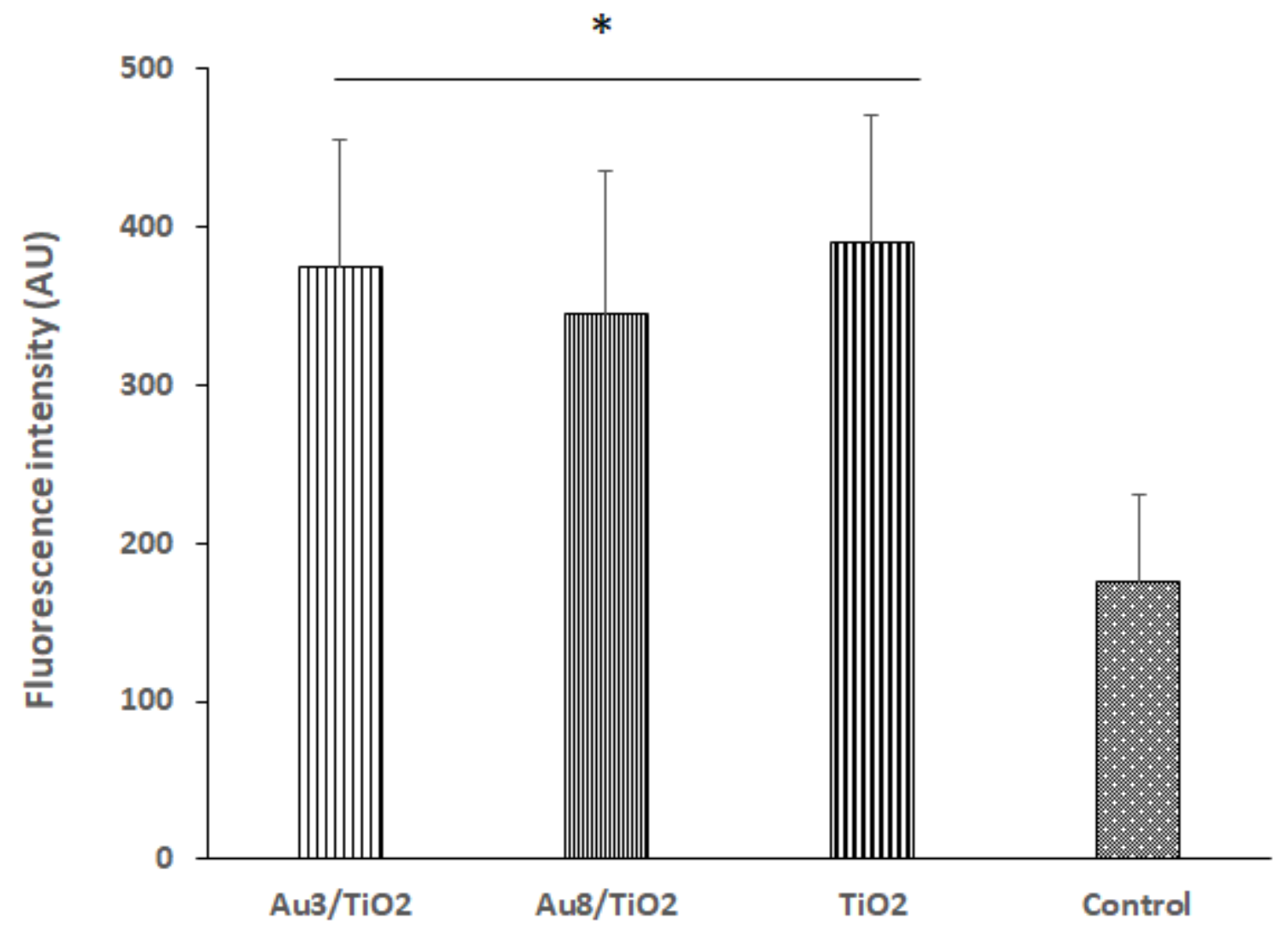

Figure 3

Effect of Au3/TiO2, Au8/TiO2 and TiO2NPs (50 $\mu \mathrm{g} \cdot \mathrm{ml}-1,6 \mathrm{~h}$ incubation) on phagocytosis of fluorescent beads by mouse peritoneal macrophages. Data are expressed as arbitrary units (AU) of fluorescence intensity and are represented as mean \pm SEM of 6 independent experiments. * significantly different from control $(p<0.05)$. 
a
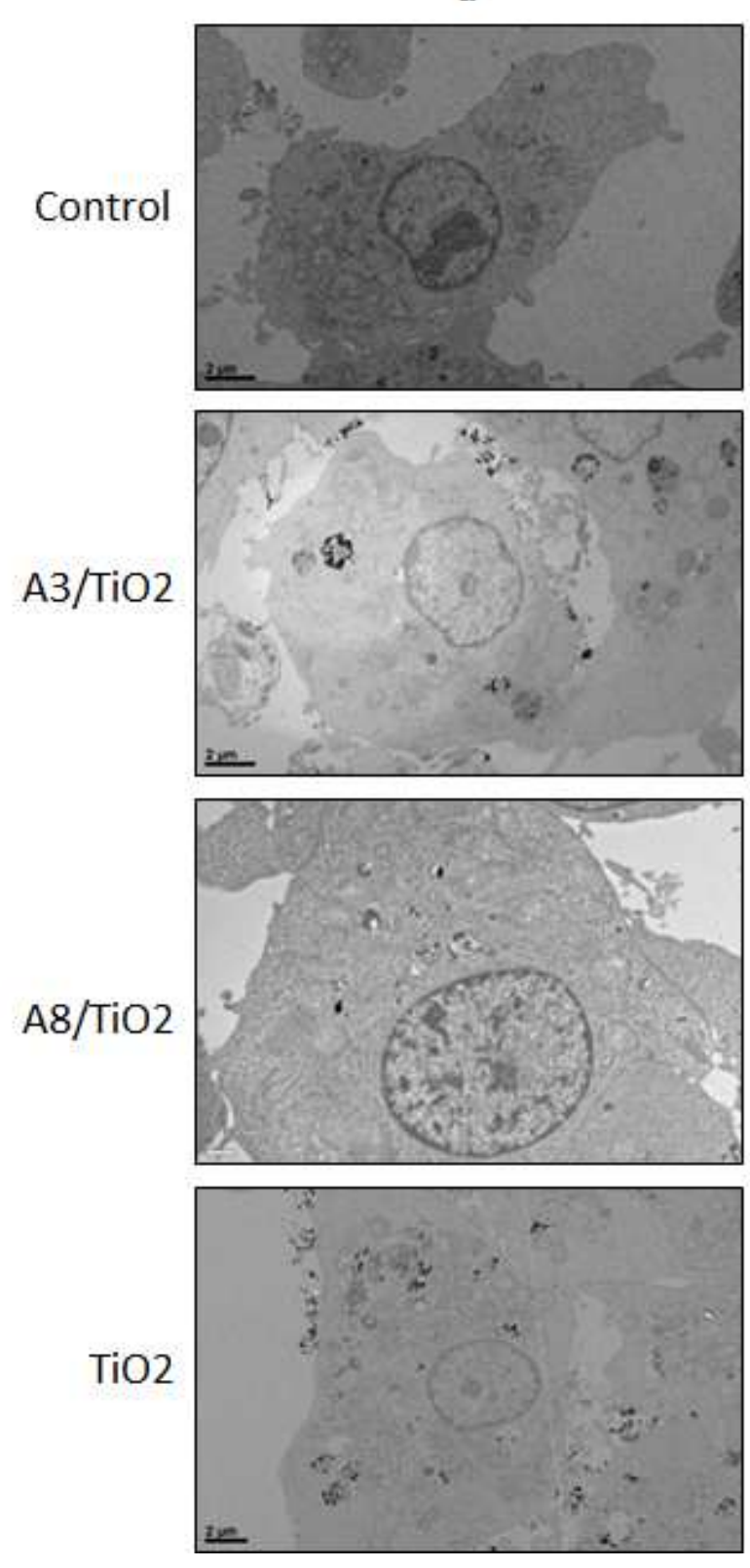

b
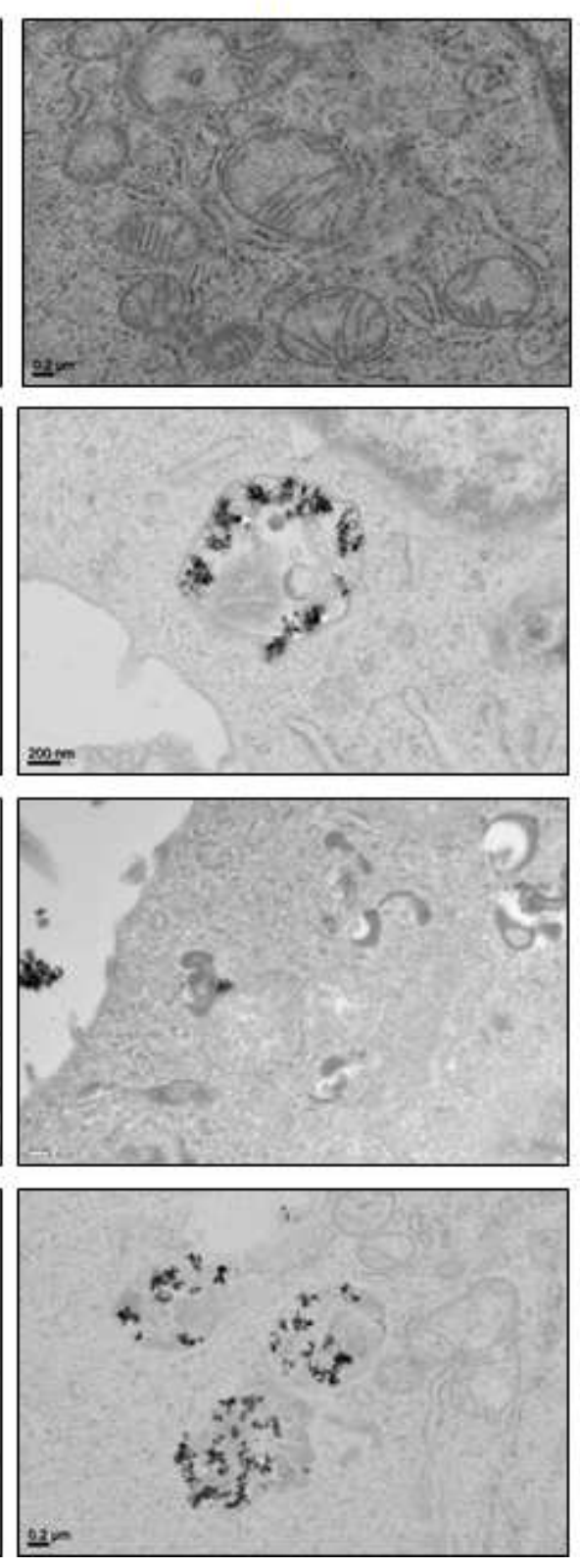
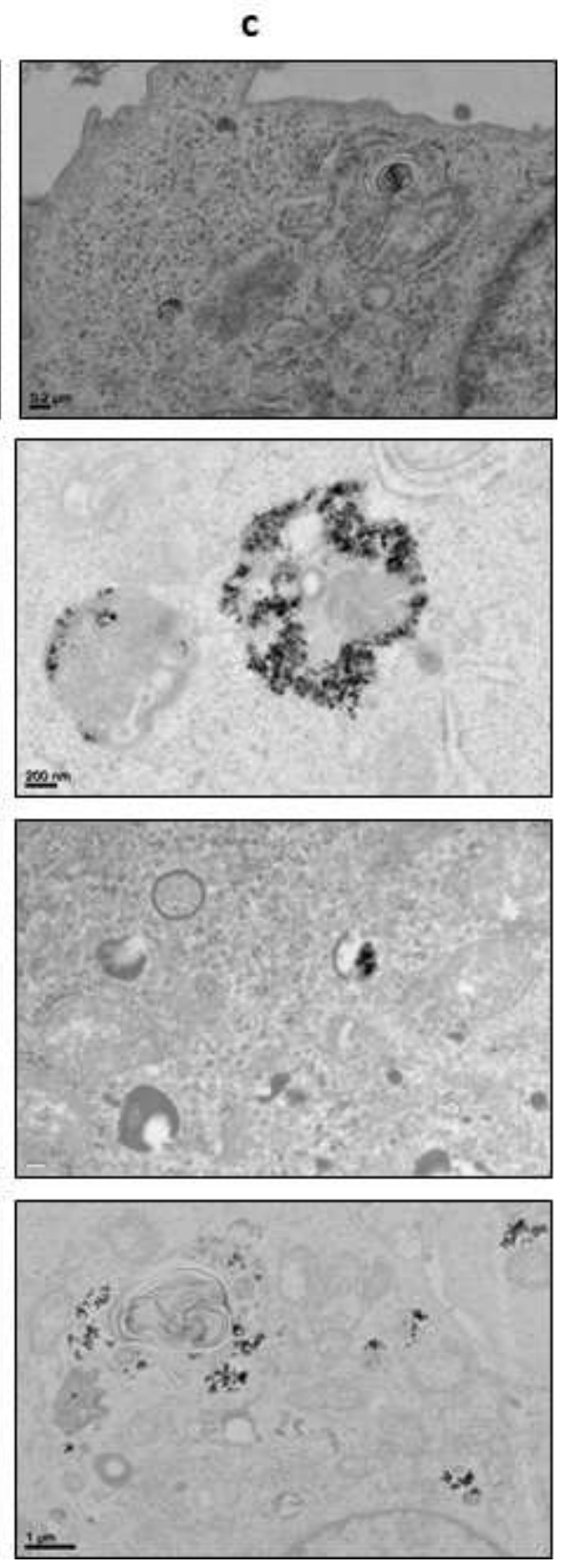

\section{Figure 4}

Transmission electron microscopy views of mouse peritoneal macrophages incubated $24 \mathrm{~h}$ with $50 \mu \mathrm{g} . \mathrm{ml}-$ 1 of Au3/TiO2, Au8/TiO2 and TiO2 NPs. The scale bar in images in column a is 2 microns, and in columns $b$ and $c$ is 0.2 microns. As observed in the images, the prevalent localization of NPs agglomerates was in cell vacuoles. No morphologic sign of cell damage was observed. 

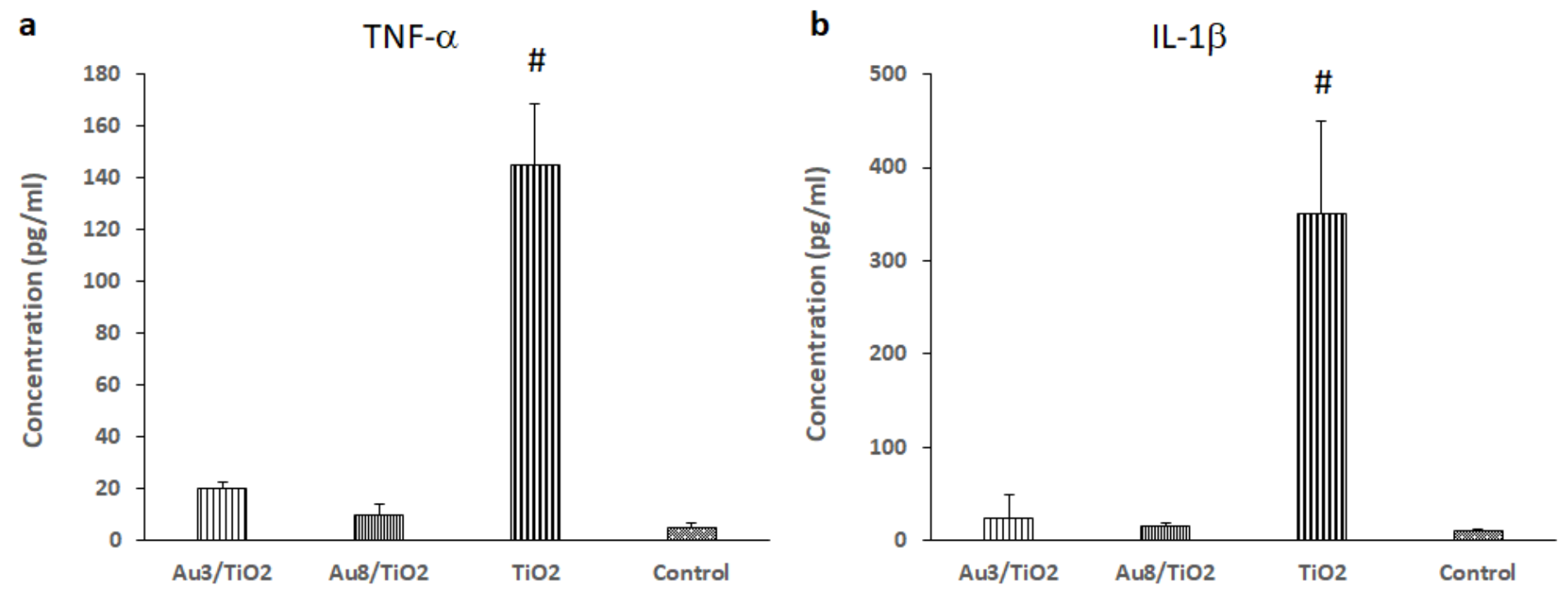

\section{Figure 5}

Effect of Au3/TiO2, Au8/TiO2 and TiO2NPs ( $50 \mu \mathrm{g} . \mathrm{ml}-1,6 \mathrm{~h}$ incubation) on TNF-a and IL-1 $\beta$ secretion by mouse peritoneal macrophages (panels a and b respectively). Data are expressed as picograms $/ \mathrm{ml}$ in cell culture medium and are represented as mean \pm SEM of 6 independent experiments. \# significantly different from control $(p<0.01)$ 


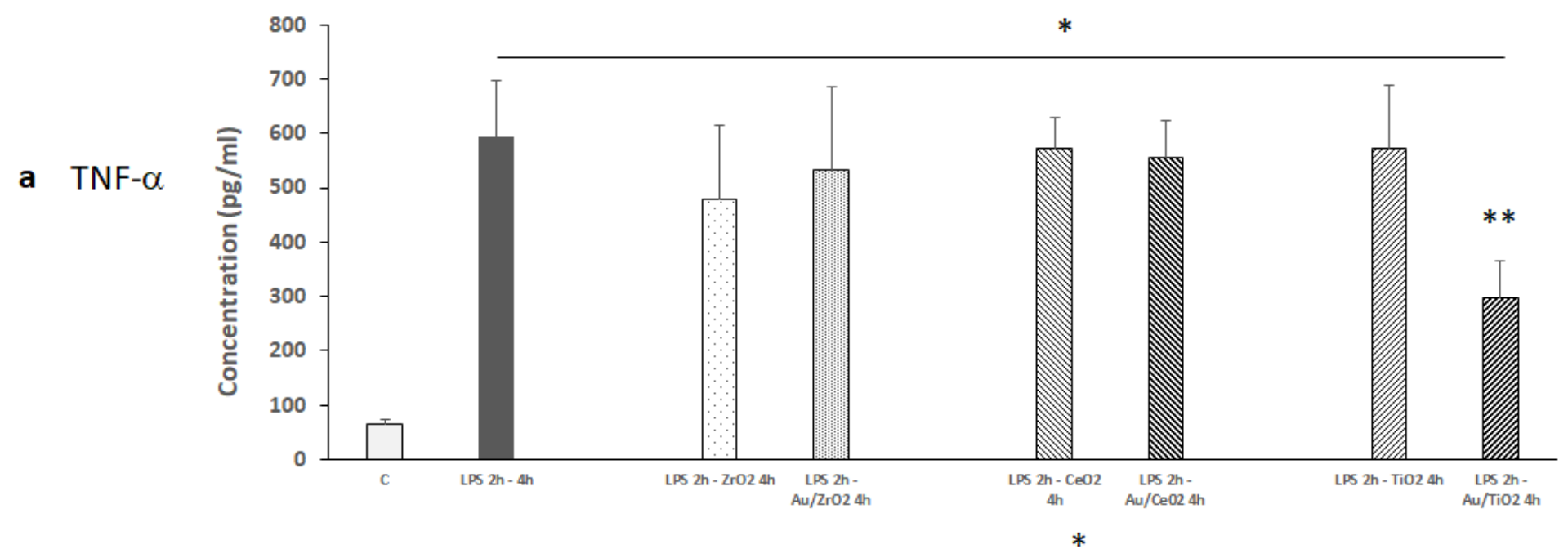

b IL-1 $\beta$

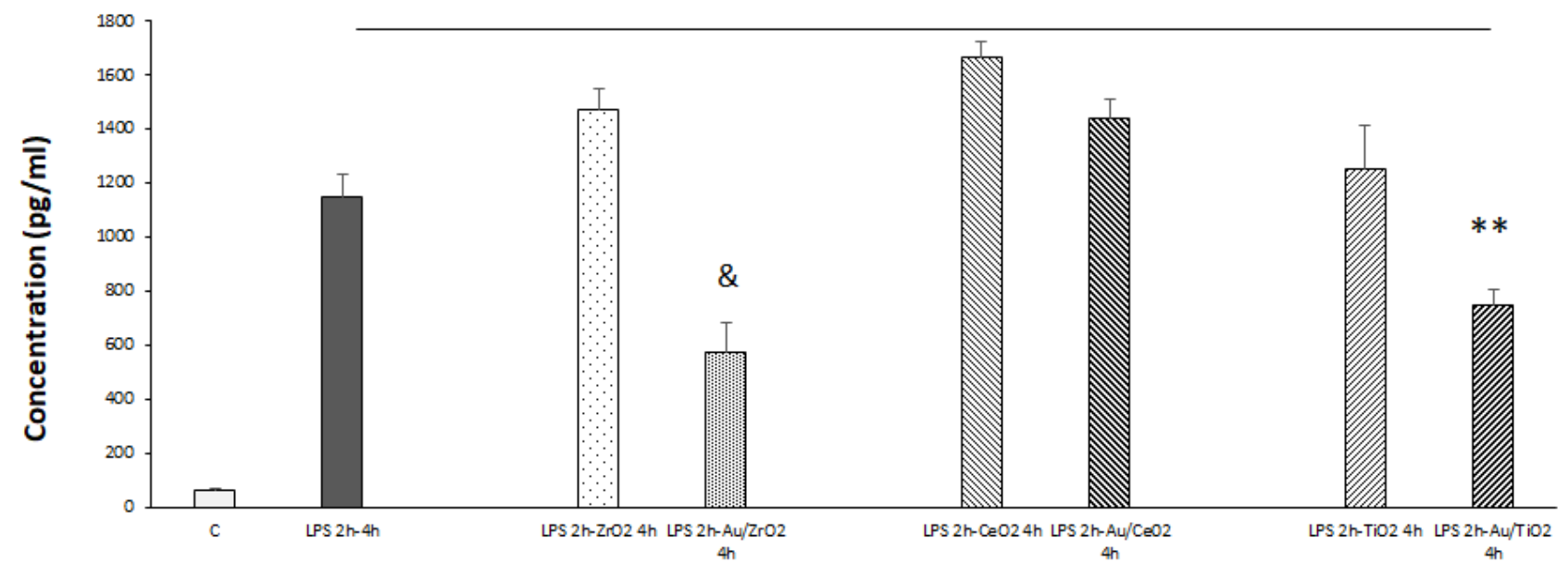

Figure 6

Effect of Au deposited on different metal oxide NPs on LPS induced TNF- $\alpha$ and IL-1 $\beta$ secretion by mouse peritoneal macrophages (Panels a and b respectively). Cells were incubated with culture media $6 \mathrm{~h}$ (control condition, C) or LPS $2 \mathrm{~h}$, and then the following $4 \mathrm{~h}$ with LPS alone or LPS plus the different NPs $(50 \mu$ g.ml-1). * significantly different from $C(p<0.05)$, ** significantly different from LPS $2 \mathrm{~h}-\mathrm{TiO} 24 \mathrm{~h}$ ( $\mathrm{p}<$ $0.05), \&$ significantly different from LPS $2 h-\mathrm{ZrO} 24 \mathrm{~h}(\mathrm{p}<0.05)$ 
a

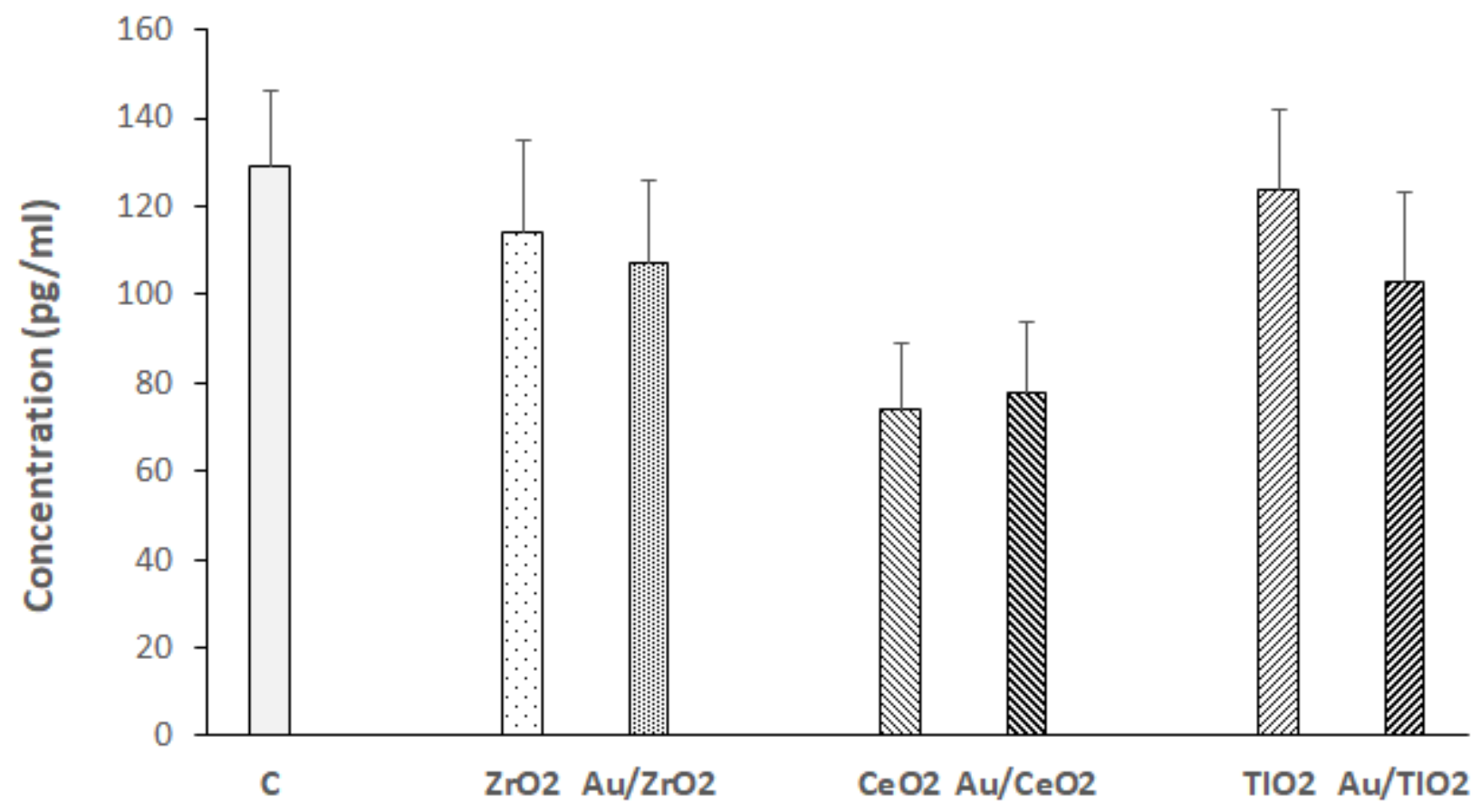

b

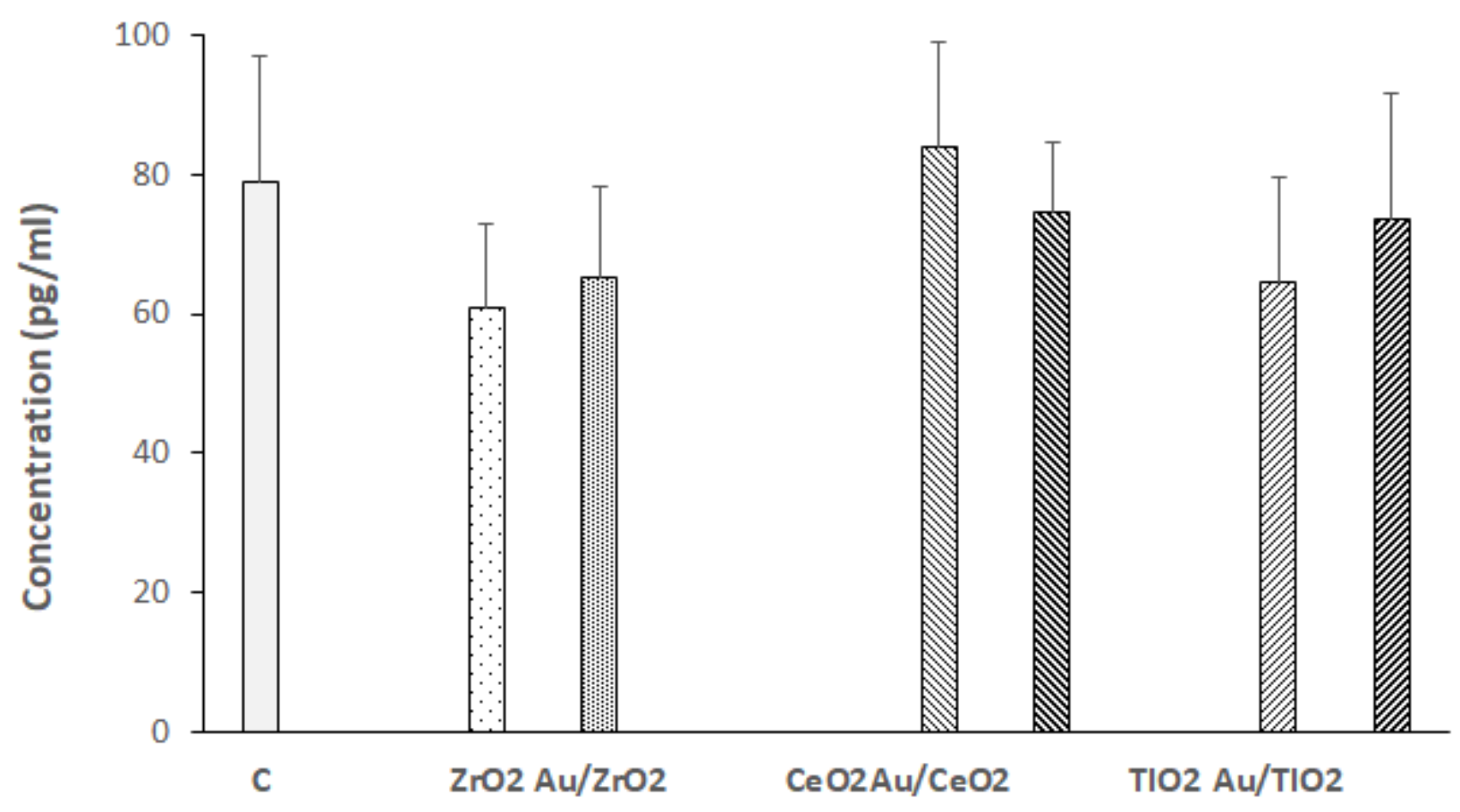

Figure 7

TNF- $\alpha$ and IL-1 $\beta$ adsorption on Au deposited on different metal oxide NPs. NPs (50 $\mu$ g.ml-1) were incubated during $6 \mathrm{~h}$ with TNF-a (150 pg.ml-1) and IL-1 $\beta$ (100 pg.ml-1) in culture media, then the cytokines were quantified in the media after centrifugation. 